\title{
Avaliação da atividade antibacteriana de filtrados de quefir artesanal*
}

\author{
RAQUELTERESINHA CZAMANSKI
}

José Maria Wiest (Orientador - UFRGS)

Banca: Soeni Bellé (CEFET-BG), Isa Beatriz Noll (UFRGS), Guiomar Pedro Bergmann (UFRGS)

Quefir é uma bebida láctea originada do Cáucaso, produzida a partir da fermentação alcoólica e ácido-lática dos grãos de quefir, que são microrganismos que vivem em perfeita simbiose. Assemelhando-se ao iogurte natural quanto ao sabor, aroma, consistência, o quefir é um alimento muito rico e por isso indicado para crianças e idosos. Possui inúmeras indicações terapêuticas, mas ainda é pouco conhecido no país. Quefir foi durante muito tempo conhecido apenas pelos povos montanheses da região Caucásica, onde é preparado com leite de ovelha ou de cabra e recebe também o nome de "milho do profeta", em alusão a Maomé, no referencial islâmico. Com base nos resultados apresentados em diversos trabalhos, comprovando a ação antimicrobiana dos grãos de quefir, prosseguiram-se os estudos pesquisando a ação antibacteriana do filtrado esterilizado de quefir artesanal, frente a diversas situações problemas. Estudou-se a possibilidade de utilizar o filtrado de quefir tradicional (artesanal ou não industrializado), previamente esterilizado, como antisséptico/ desinfetante em agroindústria familiar ou produção animal; forma alternativa aos desinfetantes químicos convencionais, considerando sua eficácia (benefício esperado/ benefício obtido), através da determinação de sua atividade antibacteriana. Foi determinada as concentrações inibitórias mínimas (CIMs) e concentrações bactericidas mínimas (CBMs) do filtrado de quefir tradicional frente a duas bactérias Gram-positivas (Staphylococcus aureus ATCC 25923, e Enterococcus faecalis ATCC 19433) e duas bactérias Gram-negativas (Escherichia coli ATCC 11229 e Salmonella enteritidis ATCC 11076 ), levando em consideração três técnicas diferentes de esterilização do filtrado, no sentido de avaliar a ação antibacteriana quanto ao tempo de exposição (cinco, quinze, trinta e sessenta minutos), presença ou ausência de suporte (aço inoxidável e pano de algodão), presença ou ausência de matéria orgânica (albumina sérica bovina, simulando sujidades de uma agroindústria). Utilizou-se a diluição serial com a técnica de sistema de tubos múltiplos e a técnica de suspensão do inóculo. Para esterilizar o filtrado de quefir utilizaram-se três diferentes técnicas: fervura convencional por quinze minutos, tindalização durante cinco minutos, por três dias consecutivos e autoclave por quinze minutos. Estas três técnicas de esterilização não apresentaram diferenças significativas entre elas. Os resultados demonstram um maior efeito bacteriostático frente a bactérias Gram-negativas e um melhor efeito bactericida frente a bactérias Gram-positivas. Staphylococcus aureus foi a bactéria que demonstrou maior resistência para a inibição (bacteriostasia); porém após sessenta minutos exposta ao quefir (75\%), a inativação (bactericidia) ocorreu em $100 \mathrm{UFC} / \mathrm{mL}$. Enquanto que a Salmonella demonstrou sensibilidade à inibição, mas nas mesmas condições, ou seja, aos sessenta minutos exposta ao quefir (75\%), a inativação ocorreu em somente $10 \mathrm{UFC} / \mathrm{mL}$. Nas primeiras vinte e quatro horas houve diferença muito significativa no desempenho do filtrado de quefir entre as linhas com e sem desinibidores bacterianos. Eis a importância do uso de desinibidores na técnica para evitar interpretações errôneas de resultados "falsos-negativos", ou seja, evitar uma leitura de morte bacteriana, quando na verdade o que ocorreu foi inibição bacteriana. Estes resultados despertam o interesse em prosseguir a avaliação de desinfetantes biológicos a serem usados na agroindústria, na saúde e na produção animal, visando à desinfecção como um controle direcionado aos microrganismos indesejáveis em situações problemas específicos, dificultando a transmissão ou a redução da dose infectante.

Descritores: quefir artesanal, laticínios, ácido lático, bactérias; alimentos.

* Dissertação de Mestrado no 351 (Especialidade: Medicina Veterinária Preventiva). 96f. Programa de Pós-Graduação em Ciências Veterinárias da Faculdade de Veterinária - UFRGS, Porto Alegre/RS. CORRESPONDÊNCIA: R. T. Czamanski [czara@bol. com.br]. 


\title{
Valuation from antibacterial activity of artesan kefir's filtered**
}

\author{
RAQUELTERESINHA CZAMANSKI
}

José Maria Wiest (Adviser - UFRGS)

Committee: Soeni Bellé (CEFET-BG), Isa Beatriz Noll (UFRGS), Guiomar Pedro Bergmann (UFRGS)

Kefir is a milky beverage originated of Caucasu, made by lacteo-acid and alcoholic fermentation of kefir grains which are microorganisms that live in perfect symbiosis. It seems like natural yogurt as taste, smell, consistence, kefir is a food very rich and that's because it's indicated for children and old ages. It has countless therapeutical indications, but it's still unknown in Brazil. Kefir was, during a very long time, known only by montainese people from the Caucasus' region, where is made with sheep or she-goat milk and it also recives the name of "prophet corn", in Maome allusion, on the Islamic reference. Throughout the shown results in several works, proving kefir grains' antimicrobian action, the studies went on searching the artisan kefir sterilized filtered's antibacterial action, front the several situations problems. Showed the possibility of use the tradicional kefir's filtered (artisan or not industrialized), previous sterilized, as antiseptic/disinfectant in familiar agroindustrial or animal production; alternative from to the conventional chemical desinfectants, considering its efficiency (expect benefit/gotten benefit), throughout the determination of its antibacterial activity. The Minimum Concentrations Inhibitions (CIMs) were determined and the Minimum Concentrations Bactericide (CBMs) of the tradicional kefir's filtered front the two positives-Gram bacterias (Staphylococcus aureus ATCC 25923 and Enterococcus faecalis ATCC 19433), and two negatives-Gram bacterias (Escherichia coli ATCC 11229 and Salmonella enteritidis ATCC 11076), taking into consideration three different technics to sterilize the kefir's filtered, in perceive of evaluate the antimicrobian action as to in the exposition of time (five, fifteen, thirty and sixty minutes), presence or absence of support (stainless steel and cotton of cloth), presence or absence of organic material (albumin bovine in simulation dirts of one agroindustrial). The utilized methodology was the serial dilution with the multiple tube system technic and the inocul suspension technic. To sterilize the kefir's filtered was used three different technics: the convencional effervescence by fifteen minutes, the tindalization during five minutes, by three days successives and the autoclave by fifteen minutes. These three technics of sterilization didn't show differences significatives among them. The results shown in a bigger bacteriostatic effect into negatives-Gram bacterias and a better bactericid effect in to positives-Gram bacterias. Staphylococcus aureus demonstrated the bigger resistance bacteria of inhibition, but after the sixty minutes exposed in the kefir (75\%), inactived in $100 \mathrm{UFC} / \mathrm{mL}$. While Salmonella showed sensitivity of inhibition, but equal condition, or then, for the sixty minutes exposed in the kefir (75\%), inactived just in $10 \mathrm{UFC} / \mathrm{mL}$. At the first twenty-four hours there was very significative difference in performance of kefir's filtered among the lines with and without bacterial desinhibition. It is the importance to use desinhibition in technic to avoid false interpretation of results, or then, to avoid reading of dead bacterial, when actually what happened was bacterial inhibition. These results awake the interesting to go on the biologics disinfectants valuation to use in agroindustrial, in health and animal production, looking at disinfection how a control in to conduce undesirable microorganisms on specific situations problems, to make difficult the transmission or the reduction of infect dose.

Key words: artisan kefir, milk-food, láctico acid, bacterias, food.

Presented: 12 june 2003

** Master's Thesis no. 351 (Field: Preventive Veterinary Medicine). 96p. Postgraduate Program in Veterinary Sciences, Faculdade de Veterinária, Universidade Federal do Rio Grande do Sul (UFRGS), Porto Alegre/Brazil. CORRESPONDENCE: R. T. Czamanski [czara@bol.com.br]. 